\title{
PREPARATION OF CaO-BASED PELLET USING RICE HUSK ASH VIA GRANULATION METHOD FOR POTENTIAL $\mathrm{CO}_{2}$ CAPTURE
}

\author{
Farah Diana Mohd DaUd ${ }^{1 *}$, Muhammad Mirza Mohamad AzIR ${ }^{1}$, \\ MUDRIKAH SOFIA MAHMUD ${ }^{1}$, NORSHAHIDA SARIFUDDIN, \\ HAFIZAH HANIM MOHD ZAKI \\ ${ }^{1}$ Deptartment of Manufacturing and Materials Engineering, Kulliyyah of Engineering, International \\ Islamic University Malaysia, P.O. Box 10, 50728 Kuala Lumpur, Malaysia \\ *Corresponding author: farah_diana@iium.edu.my
}

(Received: $11^{\text {th }}$ July 2020; Accepted: $18^{\text {th }}$ November 2020; Published on-line: $4^{\text {th }}$ January 2021)

\begin{abstract}
CO}_{2}$ capturing has become very significant option to reduce the emission of $\mathrm{CO}_{2}$ in the atmosphere and hence, minimizing environmental issues.Among solid $\mathrm{CO}_{2}$ sorbent, calcium oxide $(\mathrm{CaO})$ is an attractive regenerable sorbent for $\mathrm{CO}_{2}$ capturing because of their reactivity and high $\mathrm{CO}_{2}$ absorption capacity. $\mathrm{CaO}$ alone suffers from rapid decay of $\mathrm{CO}_{2}$ adsorption during multiple carbonation/calcination reaction cycles. The stability of $\mathrm{CaO}$ sorbents during cyclic runs can be achieved via the incorporation of additive support materials. The silica $\left(\mathrm{SiO}_{2}\right)$ from natural sources such as rice husk is the best candidate to be used as an additive in the sorbents. However, the $\mathrm{CaO}$-based sorbent in finely generated powders are prone to severe attrition problems. Therefore, this research focuses on preparation of $\mathrm{CaO}$-based pellets by using rice husk ash (RHA) via granulation method. The result of the raw materials confirmed that $\mathrm{Ca}(\mathrm{OH})_{2}$ have crystalline structure with finely distributed grains and RHA exhibit amorphous structure with randomly oriented size grains. Based on the XRD, it is confirmed that the insertion of RHA does not alter the phase structure of the pellets. Each ratio yield different intensity value and has formation of new peaks after sintering. Meanwhile, the microstructures of the pellets show that the pores reduced as the calcination temperature increased while the incorporation of RHA caused the pores size increased with randomly oriented shape. These findings indicate that the optimum value for the pellets is with the $\mathrm{Ca}(\mathrm{OH})_{2}: \mathrm{RHA}$ ratio of $80: 20$ and calcination temperature of $750{ }^{\circ} \mathrm{C}$.
\end{abstract}

\begin{abstract}
ABSTRAK: Penangkapan $\mathrm{CO}_{2}$ telah menjadi pilihan yang sangat penting untuk mengurangkan pelepasan $\mathrm{CO}_{2}$ di atmosfer serta kesan alam sekitar. Antara penjerap $\mathrm{CO}_{2}$ pepejal, kalsium oksida $(\mathrm{CaO})$ adalah penyerapan yang menarik untuk $\mathrm{CO}_{2}$ yang ditangkap kerana kereaktifan dan kapasiti penyerapan $\mathrm{CO}_{2}$ yang tinggi. $\mathrm{CaO}$ sahaja menderita daripada pelepasan cepat penjerapan $\mathrm{CO}_{2}$ semasa kitaran tindakbalas karbonasi / kalsinasi. Kestabilan $\mathrm{CaO}$ penjerap semasa berlaku kitaran boleh dicapai melalui penggabungan bahan sokongan tambahan. Silika $\left(\mathrm{SiO}_{2}\right)$ dari sumber semula jadi seperti sekam padi (RHA) adalah calon terbaik untuk digunakan sebagai aditif dalam penjerap. Walau bagaimanapun, penjerap berasaskan $\mathrm{CaO}$ dalam bentuk serbuk halus yang dihasilkan adalah terdedah kepada masalah pergeseran yang teruk. Oleh itu, kajian ini memberi tumpuan kepada penyediaan pelet berasaskan $\mathrm{CaO}$ dengan menggunakan abu sekam beras melalui kaedah granulasi. Hasil bahan mentah mengesahkan bahawa $\mathrm{Ca}(\mathrm{OH})_{2}$ mempunyai struktur kristalografi dengan bijirin halus dan RHA yang mempamerkan struktur bukan kristal dengan butiran saiz berorientasikan secara rawak. Berdasarkan XRD, ia disahkan bahawa penyisipan RHA tidak mengubah struktur kristalografi pelet. Setiap nisbah menghasilkan nilai intensiti yang berbeza dan mempunyai pembentukan puncak baru selepas pensinteran. Sementara itu, mikrostruktur pelet menunjukkan bahawa pori-pori berkurangan apabila suhu kalsinasi meningkat sementara pembentukan RHA menyebabkan saiz pori meningkat dengan bentuk berorientasikan rawak. Penemuan ini menunjukkan bahawa nilai optimum bagi pelet adalah dengan nisbah $\mathrm{Ca}(\mathrm{OH})_{2}$ : $\mathrm{RHA}$ 80:20 dan suhu kalsinasi $750{ }^{\circ} \mathrm{C}$.
\end{abstract}




\section{INTRODUCTION}

In Malaysia, the main contribution of $\mathrm{CO}_{2}$ emission is from the energy sectors such as fossil fuels, natural gas, and coal power plants. The energy sectors in Malaysia contributed at about approximately $36 \%$ of the total global $\mathrm{CO}_{2}$ emissions in 2004 and among all of the greenhouse gases, $\mathrm{CO}_{2}$ gases responsible for $60 \%$ of greenhouse effect that cause the global warming [1]. Moreover, Malaysia plans to reduce the amount of $\mathrm{CO}_{2}$ release by $25 \%$ reduction from all sectors and this is according to Green Technology Master Plan 2017-2030 proposed by Malaysia government [2]. Thus, planning and solution must be done in order to control and resolve the problems of $\mathrm{CO}_{2}$ emissions and greenhouse gases effect.

One of the solutions to reduce the $\mathrm{CO}_{2}$ gases emitted to the atmosphere is by introducing the carbon capture and storage (CCS) technology. This technology captures up to $90 \%$ of $\mathrm{CO}_{2}$ which led to significant reduction of $\mathrm{CO}_{2}$ level in atmosphere [3]. Among the $\mathrm{CO}_{2}$ capture methods, $\mathrm{CO}_{2}$ capture by adsorption into a sorbent is the most common technique used in the industry due to its better thermal properties and high amount of $\mathrm{CO}_{2}$ adsorption [4]. The adsorbent materials are usually made from ceramic materials such as $\mathrm{CaO}, \mathrm{MgO}$, and $\mathrm{ZrO}_{2}$. It is well known that ceramic materials possess better thermal properties, and these materials will be acceptable to be used in the elevated temperature condition.

However, the limitation of the recent $\mathrm{CO}_{2}$ adsorbent materials is that it has low stability and reduction in reactivity in cyclic operation. Recent studies show that other additives such as $\mathrm{SiO}_{2}, \mathrm{MgO}$, and $\mathrm{Al}_{2} \mathrm{O}_{3}$ reinforced into the sorbents can improve the cycle loop of the $\mathrm{CO}_{2}$ adsorption [4]. Improvement of the $\mathrm{CO}_{2}$ adsorption is done by designing the $\mathrm{CO}_{2}$ capture technologies in the form of pellets rather than sorbents itself and the introduction of biomass resources with the pellets is one of the advantages upon using waste and eco green materials [5]. Thus, this paper aims to study the effect of cycling loops with the pellets design when introducing other additives into the sorbents. Plus, the utilization of waste materials such as rice husk ash introduced into the pellets will be a huge impact on the economic and environmental factor.

There are many methods and techniques have been done on previous study to produce $\mathrm{CaO}$-based sorbents with the addition of $\mathrm{SiO}_{2}$ including, sol-gel, wet impregnation, biotemplate via infiltration, mixing and extrusion-spheronization methods. Among all the methods mentioned above, three of the methods utilizing biomass materials, mainly from the rice husks to act as the additives inside the CaO-based sorbents while the other two methods (sol-gel and wet impregnation) used silica sources from synthetic means. Rice husk ash used as the precursor in the $\mathrm{CaO}-\mathrm{SiO}_{2}$ sorbent due to the high content of silica. Plus, the sources of rice husk are abundant and easy to obtain as it is being produced as the by-product in paddy field makes it the best candidate to be used in the $\mathrm{CaO}$-based sorbent.

Different parameters used in the preparation of the $\mathrm{CaO}-\mathrm{SiO}_{2}$ sorbent play a crucial role in determining the performance of the pellet. There are several parameters needed for the investigation and different parameters usually will give different effects on the pellet whether it will improve the performance or becoming unfavourable. One of them is amount of silica sources incorporated with the $\mathrm{CaO}$-based sorbents or the ratio amount between those two materials. Previous studies showed that different ratio or amount of silica added exhibits different cyclic adsorption performance. In one study, ratio of 3:7 RHA/CaO shown better stability over 50 cycles compared to $1: 9 \mathrm{RHA} / \mathrm{CaO}$ even though $1: 9 \mathrm{RHA} / \mathrm{CaO}$ has better carbonation conversion in early cycles [6]. Meanwhile, in the other study, 10\%, 20\%, 30\%, $40 \%$ and $50 \%$ of RHA added into the CaO-based sorbent. Initially, the ratio of $20 \%$ RHA express the highest $\mathrm{CO}_{2}$ adsorption compare to other ratios but it reduces significantly started 
at the first cycle. Then, it is observed that $40 \%$ and $50 \%$ RHA into the $\mathrm{CaO}$ sorbent maintained the highest $\mathrm{CO}_{2}$ capture over the nine cycles [7].

The main objective of this paper is to prepare CaO-based pellet with addition of RHA as the sacrificial bio-template through granulation method. The pellets were prepared according to two different ratios and undergo calcination process at $750^{\circ} \mathrm{C}$. The effect of RHA addition and calcination at $750^{\circ} \mathrm{C}$ on the properties of $\mathrm{CaO}$-based pellets were examined through the phase structure and morphological characteristics.

\section{EXPERIMENTAL}

\subsection{Materials}

Calcium hydroxide from R\&M Chemical Sdn. Bhd. was selected as the calcium precursor. The rice husk ash (RHA) as the biotemplate material was obtained from MARDI Perlis.

\subsection{Preparation of the RHA}

Initially, RHA is oven-dried at $70^{\circ} \mathrm{C}$ overnight to eliminate moisture. Then, the fine powder of RHA is obtained by ball milling process at $200 \mathrm{rpm}$ for 1 hour. Finally, the ball milled RHA was sieved at the size range of $50 \mu \mathrm{m}$ to $90 \mu \mathrm{m}$.

\subsection{Preparation of the Sorbent Pellets}

Next, $\mathrm{Ca}(\mathrm{OH})_{2}$ and RHA powders were weighed according to two different ratios as shown in Table 1. At first, the weighed materials were vigorously mixed in a granulator machine at $73 \mathrm{rpm}$ speed for 10 minutes. Then, the mixture undergoes granulation process at the speed of $1700 \mathrm{rpm}$ and simultaneously wetted by spraying $300 \mathrm{ml}$ of deionized water. After the granulation process, the $\mathrm{Ca}(\mathrm{OH})_{2}$ - $\mathrm{RHA}$ pellet was obtained in spherical shape and randomly in size. Lastly, the $\mathrm{CaO}-\mathrm{SiO}_{2}$ pellets were obtained after calcination process in furnace at $750^{\circ} \mathrm{C}$.

Table 1: Two different ratios of $\mathrm{Ca}(\mathrm{OH})_{2}$ and RHA with different weight of each ratio

\begin{tabular}{ccc}
\hline Ratio of $\mathrm{Ca}(\mathrm{OH})_{2}$ and RHA & Weight of $\mathbf{C a}(\mathbf{O H})_{2}(\mathrm{~g})$ & Weight of RHA $(\mathrm{g})$ \\
\hline $\mathbf{8 0 : 2 0}$ & 800 & 200 \\
$\mathbf{7 0 : 3 0}$ & 700 & 300 \\
\hline
\end{tabular}

\subsection{Characterization}

\subsubsection{X-Ray Diffraction (XRD)}

The phase structure of $\mathrm{Ca}(\mathrm{OH})_{2}$, RHA and the prepared $\mathrm{CaO}-\mathrm{SiO}_{2}$ pellets, before and after calcination at $750^{\circ} \mathrm{C}$ was examined by X-Ray Diffractometer (XRD) model BRUKER D2 PHASER.

\subsubsection{Scanning Electron Microscopy (SEM)}

The morphological characteristic of raw materials $\left(\mathrm{Ca}(\mathrm{OH})_{2}\right.$ and RHA) and the prepared $\mathrm{CaO}-\mathrm{SiO}_{2}$ pellets at different ratio, before and after calcination process was investigated by JSM-IT100 Scanning Electron Microscopy (SEM) machine manufactured by JEOL. 


\section{RESULTS AND DISCUSSION}

\subsection{Analysis on the Raw Materials}

Fig. 1(a) and 1(b) show the XRD pattern of $\mathrm{Ca}(\mathrm{OH})_{2}$ and RHA at different scale of intensity. Based on the Fig. 1(a), sharp peaks at $2 \theta=18.1^{\circ}, 29.45^{\circ}, 34.15^{\circ}, 47.25^{\circ}$ and $50.85^{\circ}$ proved the crystalline structure of $\mathrm{Ca}(\mathrm{OH})_{2}$. Whereas Fig. 1(b) indicated broad peak, centered at about $2 \theta=23^{\circ}$ which confirms the amorphous structure of RHA. It is common that silica contain in RHA has amorphous structure, and its transformation to crytalline structure will occur when temperature is increased beyond $700^{\circ} \mathrm{C}$ [9]
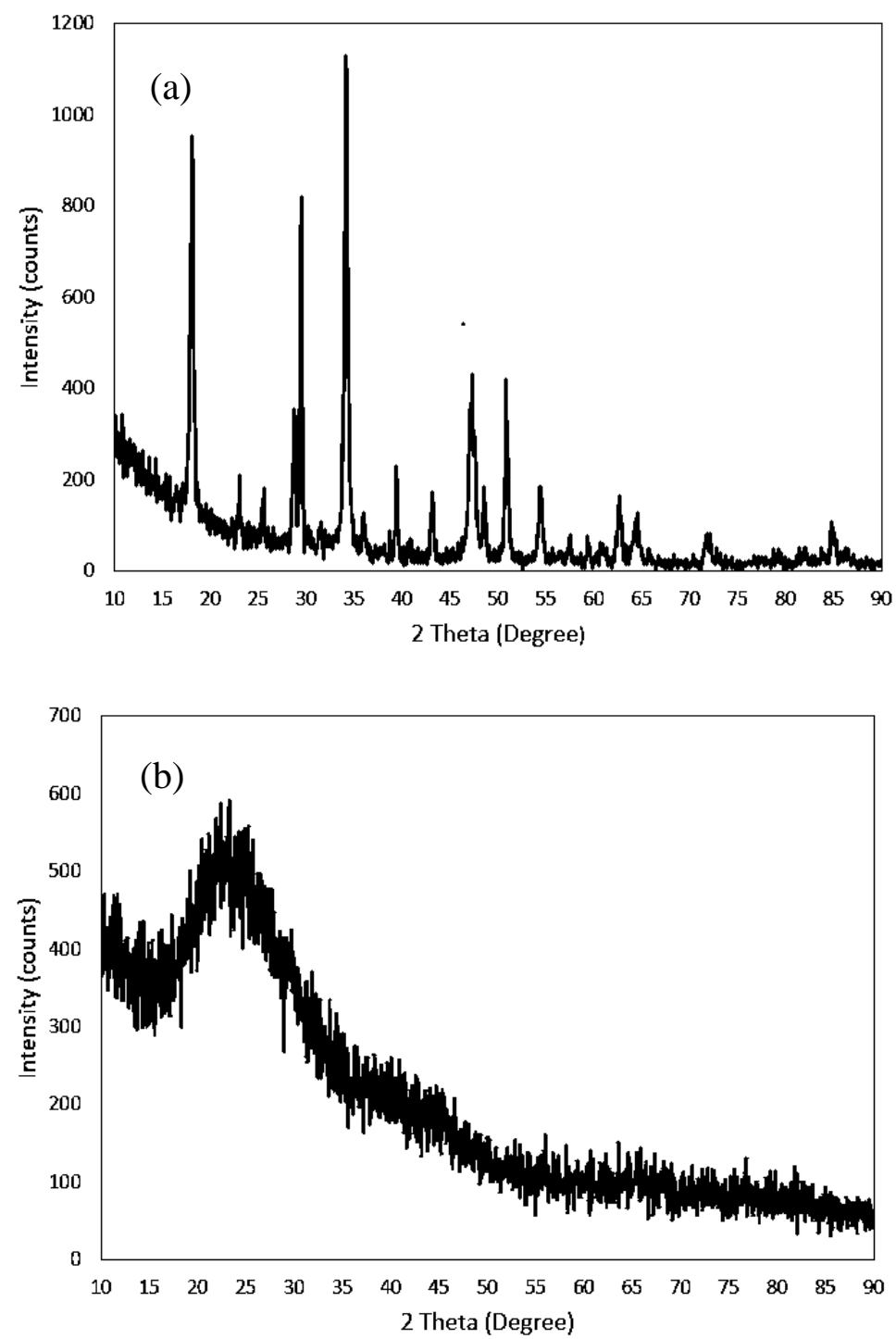

Fig.1. XRD pattern of a) $\mathrm{Ca}(\mathrm{OH})_{2}$ and b) RHA.

Fig. 2 and 3 displayed the SEM micrographs of $\mathrm{Ca}(\mathrm{OH})_{2}$ and RHA. It has been observed for $\mathrm{Ca}(\mathrm{OH})_{2}$ that it consist of finely dispersed, small size particles. Under X5000 magnification (Fig. 2(c)), the morphology of $\mathrm{Ca}(\mathrm{OH})_{2}$ revealed that the microstructure is in granular and agglomerated shape. While for RHA, the SEM images reveals the siliceous nature and with some porosity of the ashes. It was observed that RHA has agglomerated particles in various sizes and irregular structures. 


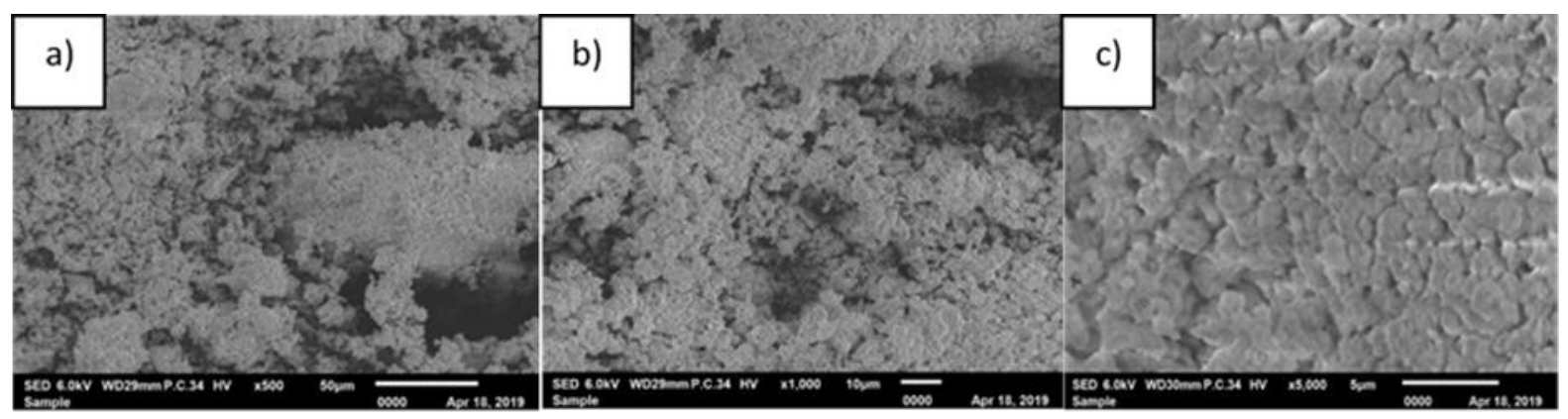

Fig. 2. SEM micrographs of $\mathrm{Ca}(\mathrm{OH})_{2}$ at magnification of a) $500 \mathrm{X}$, b) $1000 \mathrm{X}$ and c) $5000 X$.

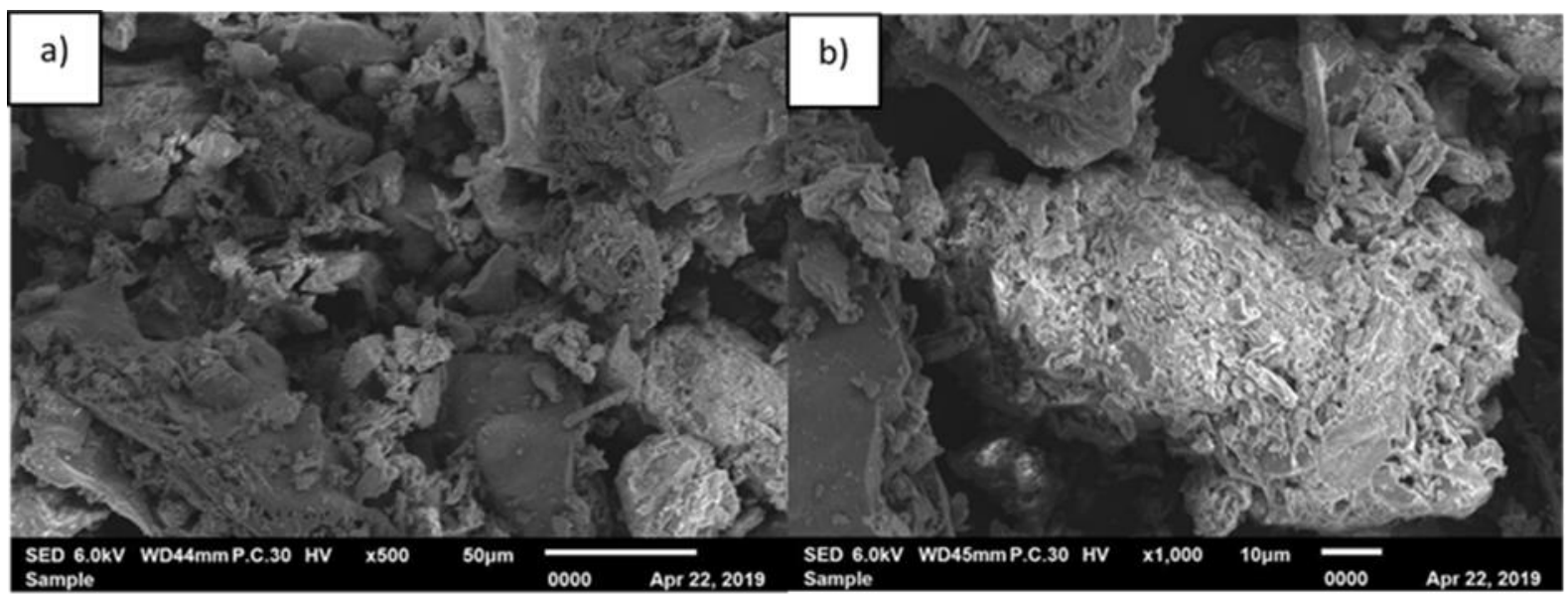

Fig 3: SEM micrographs of RHA at magnification of a) 500X and b) $x 1000 X$.

\subsection{Characterization of the Sorbent Pellets}

\subsubsection{Average Size of the Pellets}

Fig. 4 (a) and (b) show the different ratio of $\mathrm{CaO}-\mathrm{SiO}_{2}$ pellets obtained from the granulation process. As shown in Fig. 4 (a) and (b), the average size of particles for 80:20 and 70:30 pellets are $3.0 \mathrm{~mm}$ and $4.5 \mathrm{~mm}$ respectively.

The utilization of high speed of granulator and optimum amount of deionized water added during the granulation process resulted in small size of pellets. A small size of pellets was desired as the smaller the pellets, the higher the surface area of the pellets to covered for potential $\mathrm{CO}_{2}$ adsorption application. However, the significant difference in the average particles size among the two ratios is presumed to occur due to the different amount of RHA, as the $\mathrm{SiO}_{2}$ source added in $\mathrm{CaO}-\mathrm{SiO}_{2}$ pellets. The smaller size of pellets is obtained when lower amount of RHA added. Table 2 summarized the details of granulation process and the resulted average particles size for each ratio before undergo calcination process at $750^{\circ} \mathrm{C}$. 

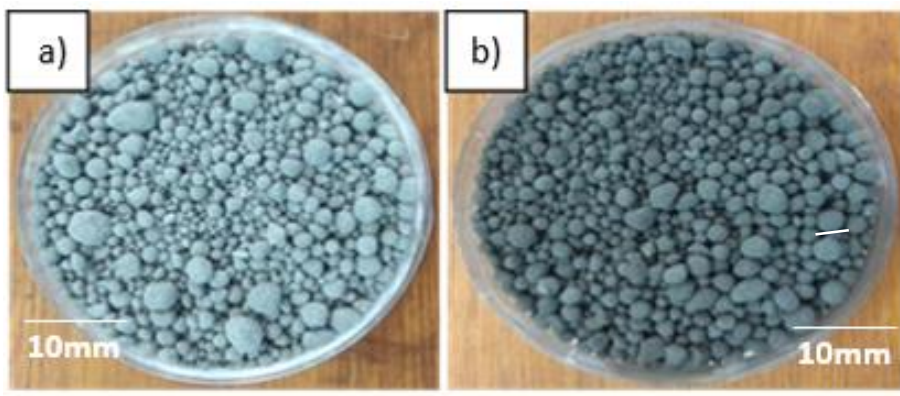

Fig. 4 .The obtained pellets from the granulation process of (a) ratio 80:20 and (b) ratio 70:30.

Table 2: Summary of the pellets obtained from two different ratios.

\begin{tabular}{cccc}
\hline $\begin{array}{c}\text { Ratio of Ca(OH) } \\
\text { and RHA }\end{array}$ & $\begin{array}{c}\text { Impeller and Chopper } \\
\text { Speed }(\mathbf{r p m})\end{array}$ & $\begin{array}{c}\text { Amount of Deionized } \\
\text { Water }(\mathbf{m l})\end{array}$ & $\begin{array}{c}\text { Average Size } \\
(\mathbf{m m})\end{array}$ \\
\hline $\mathbf{8 0 : 2 0}$ & $73,1700-1800$ & 300 & 3.0 \\
$\mathbf{7 0 : 3 0}$ & $73,1700-1800$ & 300 & 4.5 \\
\hline
\end{tabular}

Fig. 5 shows that $\mathrm{CaO}-\mathrm{SiO}_{2}$ pellets after the calcination process at $750^{\circ} \mathrm{C}$. As can be observed in Fig. 5, all pellets have significant reduction in the size of pellet which is much smaller compared to the one before the calcination. This is probably due to the elimination of moisture from the pellets and significant reduction/shrinkage in pellets size after the calcination indicates huge amount of moisture content in each pellets.

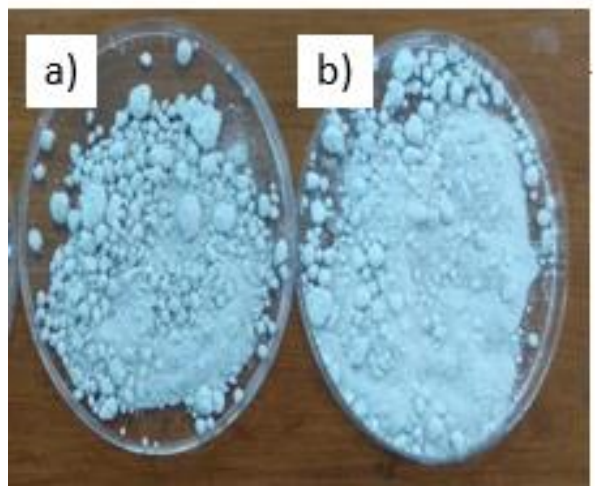

Fig. 5. Pellets after calcination of different ratio ;(a) 80:20 and (b) 70:30.

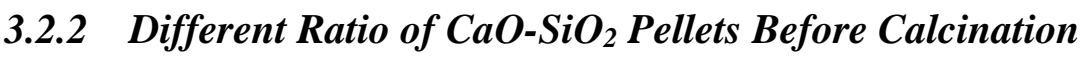

The phase structure of $\mathrm{CaO}-\mathrm{SiO}_{2}$ pellets for each ratio before the calcination process was characterized by XRD analysis, as displayed in Fig. 6 (a) and (b). The peak characteristics of $\mathrm{Ca}(\mathrm{OH})_{2}$ and $\mathrm{SiO}_{2}$ are detected in XRD pattern of all $\mathrm{CaO}-\mathrm{SiO}_{2}$ pellets. According to Fig. 6 , it is evident that the main crystalline peaks of $\mathrm{Ca}(\mathrm{OH})_{2}$ were detected at about $2 \theta=28.76^{\circ}$, 
$34.17^{\circ}, 47.21^{\circ}$ and $62.78^{\circ}$. However, the intensity for each peak was decreased with increasing amount of RHA added. Besides, the characteristics peak of silica also could be observed from the XRD pattern, however, the intensity of the peaks was very low due to its amorphous nature. The silica peak centered about $2 \theta=23^{\circ}$ was observed in both XRD spectras of pellets prepared.
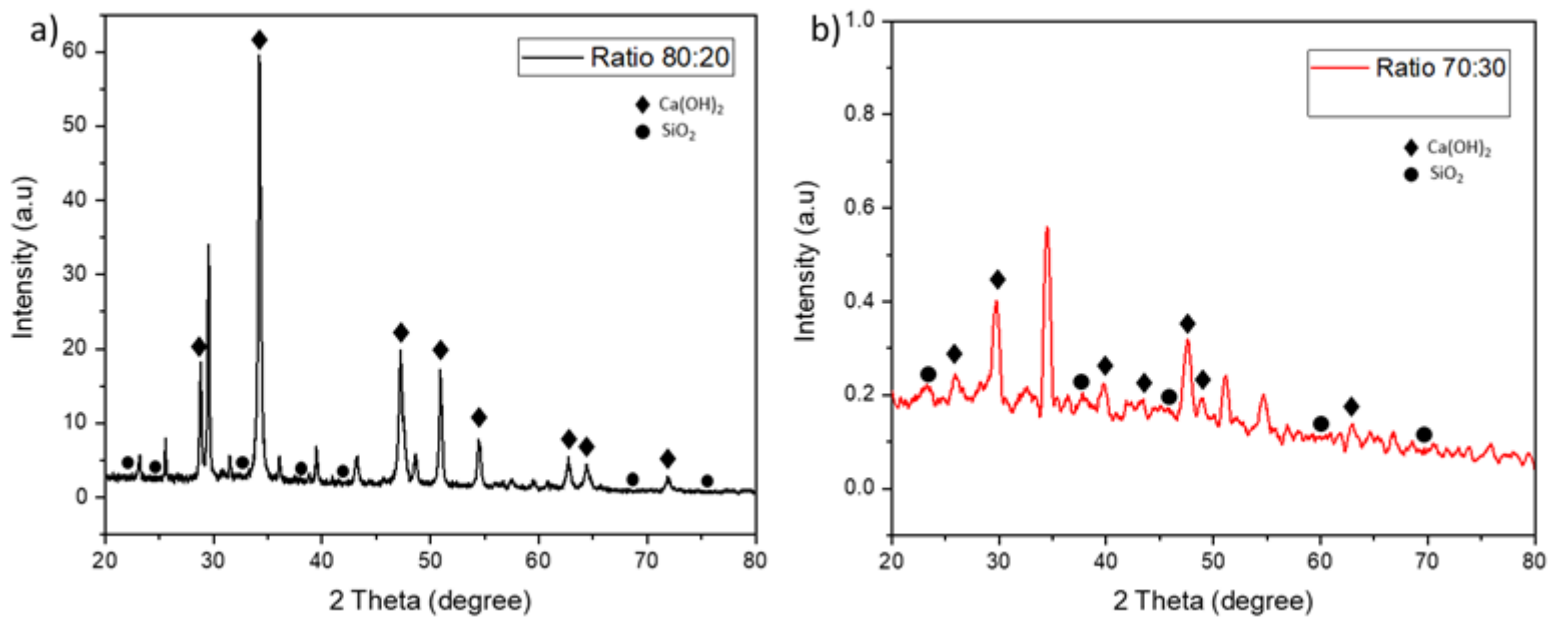

Fig. 6. XRD spectra for different ratio of $\mathrm{CaO}-\mathrm{SiO}_{2}$ before calcination, (a) $80: 20$ and (b) $70: 30$

Different ratio of RHA addition in the $\mathrm{CaO}-\mathrm{SiO}_{2}$ pellets as the biomass sacrificial template did not disrupted the crystalline structure of the calcium precursor. This is proved by the almost similar XRD pattern obtained from the $\mathrm{CaO}-\mathrm{SiO}_{2}$ pellets with the XRD pattern of the raw $\mathrm{Ca}(\mathrm{OH})_{2}$. Besides, the detection of similar major diffraction peaks from XRD pattern of all pellets evidenced the incorporation of sacrificial biomass template materials did not modify the crystallinity of the pellets produced [8].

The SEM micrograph of the prepared $\mathrm{CaO}-\mathrm{SiO}_{2}$ pellets at different ratios were shown in Fig. 7 and 8. All the micrographs illustrated that addition of RHA had significantly altered the morphology of $\mathrm{CaO}-\mathrm{SiO}_{2}$ pellets prepared, according to the ratio. Based on Fig. 8, 80:20 pellet shows large and irregular grains size with random distribution. Meanwhile, 70:30 pellet exhibits randomly distributed, irregular, and smaller shape of microstructures. Some small needle-like or flake structure could be observed which indicates the presence of ash or biomass material inside the pellets that have been prepared. According to the micrographs obtained, increasing amount of RHA added caused the grains size to decrease significantly which lead to the development of irregular microstructures. 


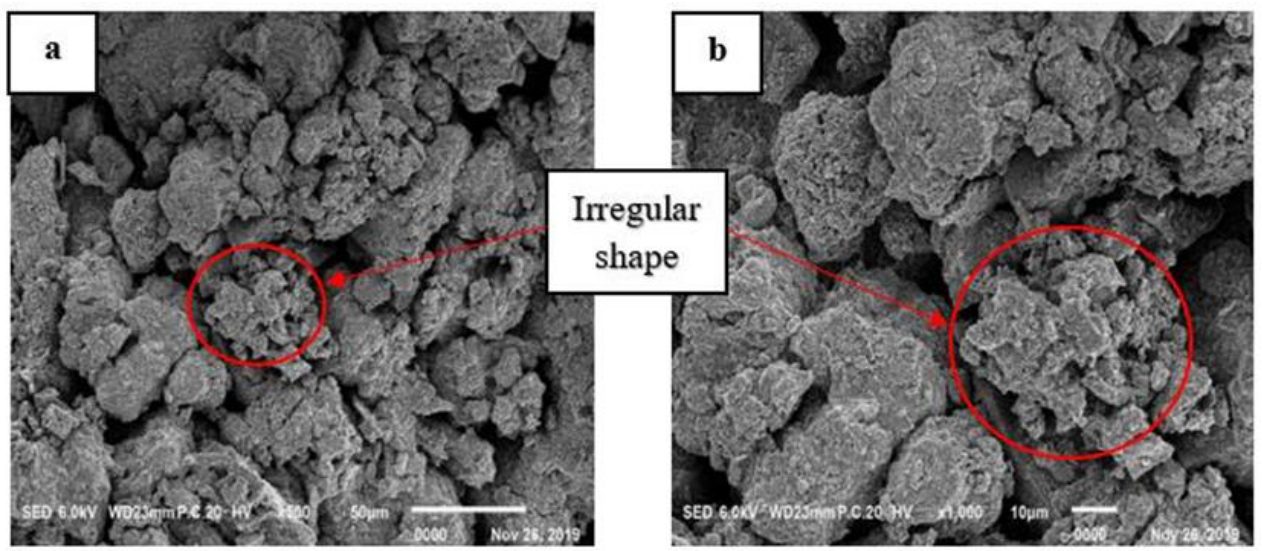

Fig.7. SEM micrographs of $\mathrm{CaO}-\mathrm{SiO}_{2}$ pellets ratio 70:30 before calcination at different magnification a) $500 \mathrm{X}$ and b) $1000 \mathrm{X}$

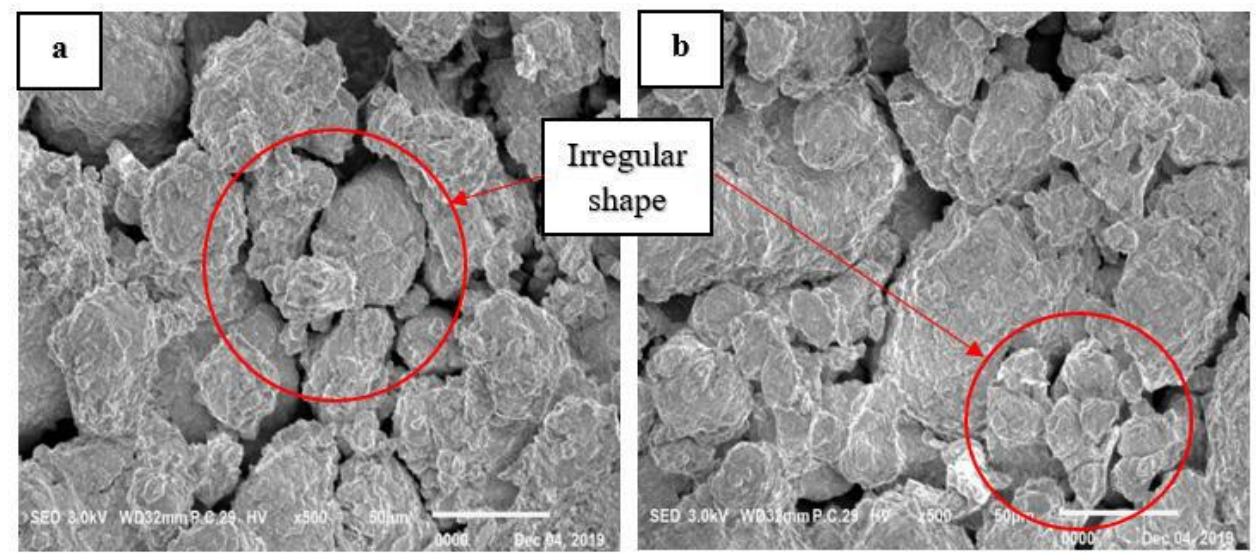

Fig.8. SEM micrographs of $\mathrm{CaO}-\mathrm{SiO}_{2}$ pellets ratio 80:20 before calcination at two different spots by magnification of $500 \mathrm{X}$

\subsubsection{Effect of Different Ratio after $750{ }^{\circ} \mathrm{C}$ Calcination}

The effect of calcination at $750^{\circ} \mathrm{C}$ on the phase structure of $\mathrm{CaO}-\mathrm{SiO}_{2}$ pellets prepared is shown in Fig. 9. Sharp peaks were detected from all of the XRD pattern obtained which confirmed the existance of crystalline phase. This is due to the formation of $\mathrm{CaO}$ after sintering at $750^{\circ} \mathrm{C}$. The $\mathrm{CaO}$ peaks can be observed at $2 \theta=29.76^{\circ}, 33.02^{\circ}, 39.49^{\circ}, 47.56^{\circ}, 51.91^{\circ}$ and $54.58^{\circ}$.

However, there is significant difference in intensity of peak at $2 \theta=29.76^{\circ}$. The highest peak intensity was observed in 70:30 pellet followed by 80:20 pellet. Supposedly, if the amount of $\mathrm{CaO}$ is higher compared to the silicate, the significant increment in peak intensity of $\mathrm{CaO}$ should be obtained whereas the silicate peaks should remain unchanged [10]. But from the XRD pattern obtained, pellet with low amount of $\mathrm{CaO}$ (70:30 pellet specifically) possessed the highest peak of $\mathrm{CaO}$. This is presumed to occur due to the calcination process at $750^{\circ} \mathrm{C}$ might have altered the phase structure of silica in RHA and thus modified the XRD pattern of all pellets. 


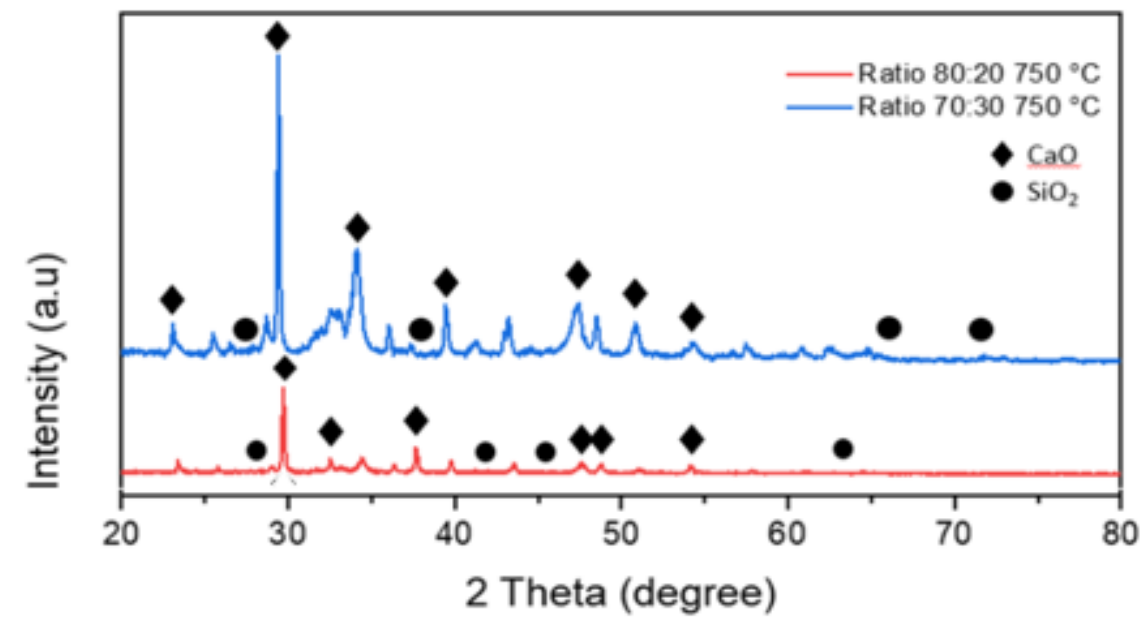

Fig.9. XRD spectra for different ratio of $\mathrm{CaO}-\mathrm{SiO}_{2}$ pellet calcined at $750^{\circ} \mathrm{C}$

Morphology of the calcined $\mathrm{CaO}-\mathrm{SiO}_{2}$ pellets for each ratio are shown in Fig. 10 and 11. After calcination at $750^{\circ} \mathrm{C}$, the formation of pores was observed in micrographs acquired. For 80:20 pellet, grains with random sized have been developed after sintering at $750^{\circ} \mathrm{C}$ with the presence of needle-like structure. The presence of needle-like structure suggests formation of a new compund resulted from the calcination of $\mathrm{CaO}-\mathrm{RHA}$ which mainly composed of $\mathrm{Ca}, \mathrm{Si}$ and $\mathrm{O}$ elements [11]. As for 70:30 pellet, the morphology consists of randomly scattered grains which is small in size as shown in Fig. 11. 70:30 pellet has irregular pores structure but not as large as compared to the pore stucture in 80:20 pellet. However, 80:20 pellet shows better porosity as the pores size were larger which caused an increased in porosity. Higher amount of well-structured pores were more preferred for $\mathrm{CO}_{2}$ capture application; in which it would contribute to an excellent performance of $\mathrm{CO}_{2}$ adsorption.

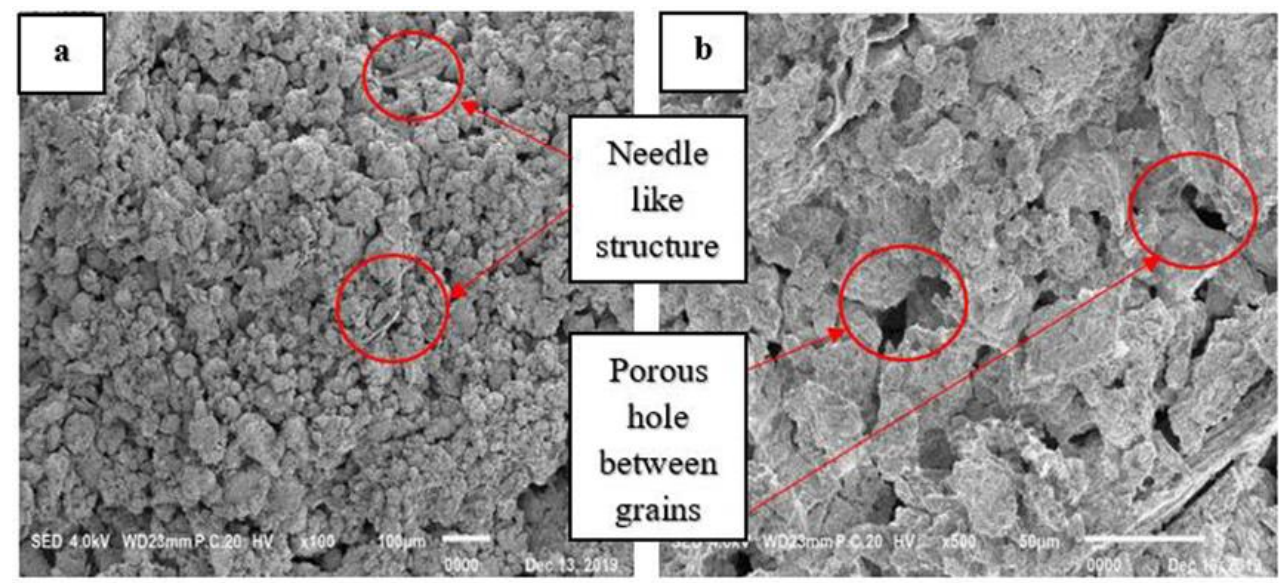

Fig.10. SEM micrographs of $\mathrm{CaO}-\mathrm{SiO}_{2}$ pellets ratio $80: 20$ after calcination at $750^{\circ} \mathrm{C}$ with different magnification a) $100 \mathrm{X}$ and b) $500 \mathrm{X}$. 


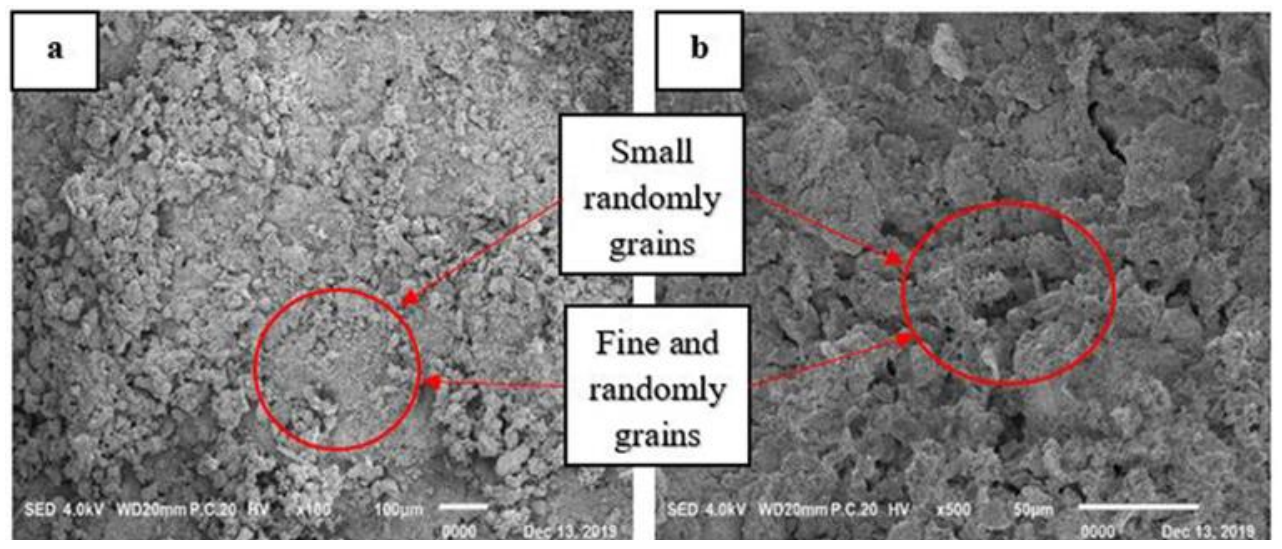

Fig.11. SEM micrographs of $\mathrm{CaO}-\mathrm{SiO}_{2}$ pellets ratio $70: 30$ after calcination at 750 ${ }^{\circ} \mathrm{C}$ with different magnification a) $100 \mathrm{X}$ and b) $500 \mathrm{X}$.

\section{CONCLUSION}

This study presented the CaO-based pellets with addition of RHA as the sacrificial biotemplate had been successfully prepared via granulation method. The calcium precursor, $\mathrm{Ca}(\mathrm{OH})_{2}$ has agglomerates and granular microstructures and RHA has an irregular and in definitive shape of microstructures. Based on the XRD analysis, the $\mathrm{Ca}(\mathrm{OH})_{2}$ has crystalline structure, while RHA has amorphous structure. XRD analysis proved that the inclusion of RHA in the $\mathrm{Ca}(\mathrm{OH})_{2}$ did not disrupted the crystalline structure of the samples and intensity of the peaks were reduced with increasing amount of RHA added. However, the calcination at $750^{\circ} \mathrm{C}$ has significantly modified the $\mathrm{XRD}$ pattern of all $\mathrm{CaO}-\mathrm{SiO}_{2}$ pellets. The sharp peaks indicated the development of crystalline $\mathrm{CaO}$ and different ratio has different peak intensity. The pellets with low amount of RHA has finer grain structure observed as for increased the amount of RHA caused the pores became agglomerate, increase in size and randomly distributed. To conclude, based from the characterization result it indicates that ratio 80:20 and calcination temperature of $750{ }^{\circ} \mathrm{C}$ were the optimum parameters to be used for the pellets production.

\section{REFERENCES}

[1] Rawshan AB, Kazi S, Sharifah Mastura SA, Mokhtar J. (2015) $\mathrm{CO}_{2}$ emissions, energy consumption, economic and population growth in Malaysia. Renew.Sust. Energ. Rev., 41:594-601.

[2] Alifah Z. (2017). Malaysia to slash another 25\% of CO2 emission by 2030. Retrieved from: https:/themalaysianreserve.com/2017/06/21/malaysia-slash-another-25- co2-emission-2030/

[3] Naeem MA, Armutlulu A, Kierzkowska A \& Müller CR. (2017) Development of Highperformance $\mathrm{CaO}$-based $\mathrm{CO}_{2}$ Sorbents Stabilized with $\mathrm{Al}_{2} \mathrm{O}_{3}$ or $\mathrm{MgO}$. Energy Procedia, 114: 158166.

[4] Zhang Z, Tohid NGB, Muftah HEN. (2018) Carbon Capture. Chapter 4.5, Exergetic, Energetic Environ. Dimensions, 997-1016.

[5] Wang J, Huang L, Yang R, Zhang Z, Wu J, Gao Y, Wang Q, O'Hare D, Zhong Z. (2014) Recent advances in solid sorbents for $\mathrm{CO}_{2}$ capture and new development trends. Energy. Environ. Sci., 7:3478-3518. 
[6] Monica BG, Jose, MV, Antonio P, Pedro ESJ, Luis APM. (2018) Low-cost Ca-based composites synthesized by biotemplate method for thermochemical energy storage of concentrated solar power. Appl.Energy, 210:108-116.

[7] Mustakimah M, Suzana Y, Armando TQ, Tetsuya K. (2018) Utilization of rice husk to enhance calcium oxide-based sorbent prepared from waste cockle shells for cyclic $\mathrm{CO}_{2}$ capture in hightemperature condition. Environ. Sci. Pollut. Res., 26:33882-33896.

[8] Liu, W., An. H., Qin, C., Yin, J., Wang, G., Feng, B., Xu, M. (2012) Performance Enhancement of Calcium Oxide Sorbents for Cyclic CO2 Capture: A Review. Energ. Fuels, 26:275-2767.

[9] María E, Vasilije M, Edward JA. (2016) Calcium looping sorbents for $\mathrm{CO}_{2}$ capture. Appl. Energy, 180:722-742.

[10] Sanchez-Jimenez PE, Perez-Maqueda LA, \& Valverde JM. (2014) Nanosilica supported CaO: a regenerable and mechanically hard $\mathrm{CO}_{2}$ sorbent at Ca-looping conditions. Appl. Energy, 118:9299.

[11] Li Y, Zhao C, Ren Q, Duan L, Chen H, Chen X. (2009) Effect of rice husk ash addition on $\mathrm{CO}_{2}$ capture behavior of calcium-based sorbent during calcium looping cycle. Full Processing Technology, 90: 825-834. 